\title{
Development of High Protein and Vitamin A Flakes from Sweet Potato Roots and Leaves
}

\author{
Nicanor Obiero Odongo, George Ooko Abong', Michael Wandayi Okoth, Edward G. Karuri \\ Department of Food Science, Nutrition and Technology, University of Nairobi, Nairobi, Kenya \\ Email: georkoyo@yahoo.com
}

Received 19 June 2015; accepted 9 July 2015; published 14 July 2015

Copyright (C) 2015 by authors and OALib.

This work is licensed under the Creative Commons Attribution International License (CC BY). http://creativecommons.org/licenses/by/4.0/

(c) (i) Open Access

\section{Abstract}

Sweet potato (Ipomoea batatas) is one of the most important, versatile and unexploited crops in Kenya. The crop is well adapted to smallholder farming systems, inexpensive to produce, relatively drought tolerant and gives high yields even with minimum inputs. Although widely produced in Kenya, sweet potato remains primarily a subsistence crop. Lack of organized marketing, limited consumer interest and low value addition activities are some of the factors that have contributed to low commercialization of the crop. The overall objective of the current study was to investigate the suitability of incorporating sweet potato leaves into the roots to produce nutritious sweet potato flakes with high vitamin A and protein content. Sweet potato roots were cured to increase the endogenous amylase enzyme and then washed and pre-cooked to enable starch hydrolysis to increase sweetness of the flakes and then heated to boiling to enable mashing. Dried sweet potato leaves powder was then added to the mash sweet potato roots at varying percentages and then dried using single drum drier. Addition of sweet potato leaves was found to significantly $(p<0.05)$ increase protein content from $6.6 \%$ protein to $15.40 \%$ when the leaves constituted $50 \%$ of the flakes. Beta carotene content of the flakes decreased from $7986 \mu \mathrm{g} / 100 \mathrm{~g}$ when no leaves were added to $3979 \mu \mathrm{g} / 100 \mathrm{~g}$ when the leaves constituted $50 \%$ of the flakes. The addition of the leaves reduced the overall acceptability. Colour was the most adversely affected while texture was the least affected by the addition of sweet potato leaves. However, all the flakes with up to $30 \%$ leaves were acceptable to the panelists with respect to colour, taste, texture and overall acceptability. Incorporating sweet potato leaves into the roots can therefore improve sweet potato protein and hence improve nutrition and value addition of root-based products such as flakes and flour.

\section{Keywords}

Sweet Potato Roots, Protein Content, $\beta$-Carotene, Flakes

Subject Areas: Food Science \& Technology

\footnotetext{
*Corresponding author.

How to cite this paper: Odongo, N.O., Abong', G.O., Okoth, M.W. and Karuri, E.G. (2015) Development of High Protein and Vitamin A Flakes from Sweet Potato Roots and Leaves. Open Access Library Journal, 2: e1573. 


\section{Introduction}

Sweet potato (Ipomoea batatas) is a hardy and nutritious staple food crop, which is grown throughout the humid tropical and subtropical regions of the world. It is a perennial plant of the family Convolvulaceae and is among the most important food crops in the world and is ranked seventh based on total production and the fifth most important crop in developing countries [1]. It is produced in both high and low technology input agricultural systems.

In Kenya, sweet potato growing is mainly concentrated in eastern Kenya including Kakamega, Bungoma, Busia, Homa Bay, and Kisiicounties. It is also grown to a small extent in the coastal and central regions with production being concentrated in mid-altitudes i.e. 1000 - $1600 \mathrm{~m}$ above the sea level [1].

Orange fleshed sweet potato (OFSP) is one of the new crops that have been introduced due to its high betacarotene content. It is an excellent source of energy and important nutrients such as vitamin A that can contribute towards improvement of the nutritional status of the community [2]. The promising potential of this new crop has not gone unnoticed and hence its promotion by various organizations in sub-Saharan Africa through the Sweet Potato Action for Security and Health in Africa (SASHA) and worldwide through the Sweet Potato Initiative for Profit and Health (SPHI) [3].

Studies have demonstrated that orange fleshed sweet potato improves vitamin A status in children given that the vitamin in the OFSP is highly bioavailable [4]-[7]. Vitamin A deficiency (VAD) is a serious health issue for most of the developing countries and is known to contribute towards over 0.6 million deaths per annum. The most affected are young children and pregnant women [8]-[10]. It is important to note that both sweet potato roots and sweet potato leaves are consumed with both providing nutritional and health benefits [11].

Sweet potatoes, just like cereal and potato snacks tend to be low in protein and have poor biological value due to their limited essential amino acid content. Crude protein content of sweet potato has been reported to vary between $1 \%$ and $10 \%$ (on a dry weight basis), but this includes 10\% - 15\% non-protein nitrogenous components [12]. This amount is considerably low and therefore can be improved by addition of sweet potato leaves to the sweet potato roots since the crude protein content of the sweet potato leaf is higher with a range of $26 \%$ to $33 \%$ of DM [13]. Therefore, the sweet potato leaves can be used to improve the protein content of sweet potato roots under appropriate combinations.

In addition to high protein content, the sweet potato leaves have high antioxidative polyphenolics such as anthocyanins and phenolic acids such as caffeic, monocafeoylquinic (chlorogenic), dicaffeoylquinic, and tricaffeoylquinic acids [14] [15], and are superior in this regard to other commercial vegetables [16] [17]. Despite these nutritional benefits, the use of potato leaves has been limited to animal feed.

Ready-to-eat sweet potato breakfast cereals have been developed [18], though with limited protein and vitamin A. Flakes are major universal food consumed by nearly all the population age groups but mostly by children who are below 10 years and therefore a suitable vehicle to transport the provitamin A in the OFSP to these vulnerable children who are at the risk of becoming blind and even dying due to vitamin A deficiency. Furthermore, processing sweet potato roots and leaves into flakes is advantageous since flakes have long shelf-life and are easy to store and to transport. The present study was therefore to develop protein and vitamin A rich OFSP flakes using sweet potato roots and leaves.

\section{Materials and Methodology}

\subsection{Raw Materials}

Raw orange fleshed sweet potatoes used in the current study were mature roots of variety SPK 004 and its tender sweet potato leaves from Kenya Agricultural Research Centre (KARI) Muguga. They were grown following standard cultural practices and harvested at maturity from the KARI Centre and transported to the University of Nairobi, Department of Food Science, Nutrition and Technology for analysis. Figure 1 shows the research design that was adopted for the current study.

The morphological pictures of the OFSP roots and leaves used for the study are presented in Figure 2.

\subsection{Curing}

Sweet potato roots were cured for 5 days at a temperature of $32.2^{\circ} \mathrm{C}$ and a relative humidity of $85 \%$ as described by Ikemiya and Deobald (1966) [19]. 


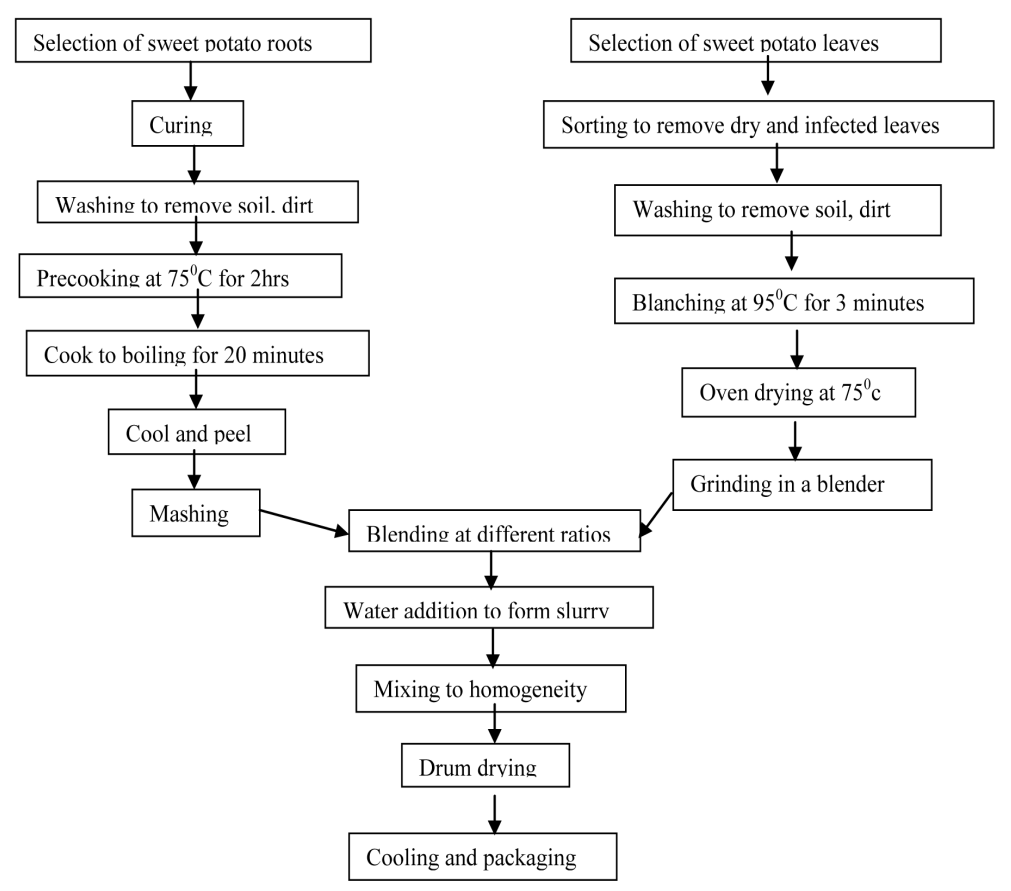

Figure 1. Flow diagram for preparation of OFSP roots-tuber flakes.
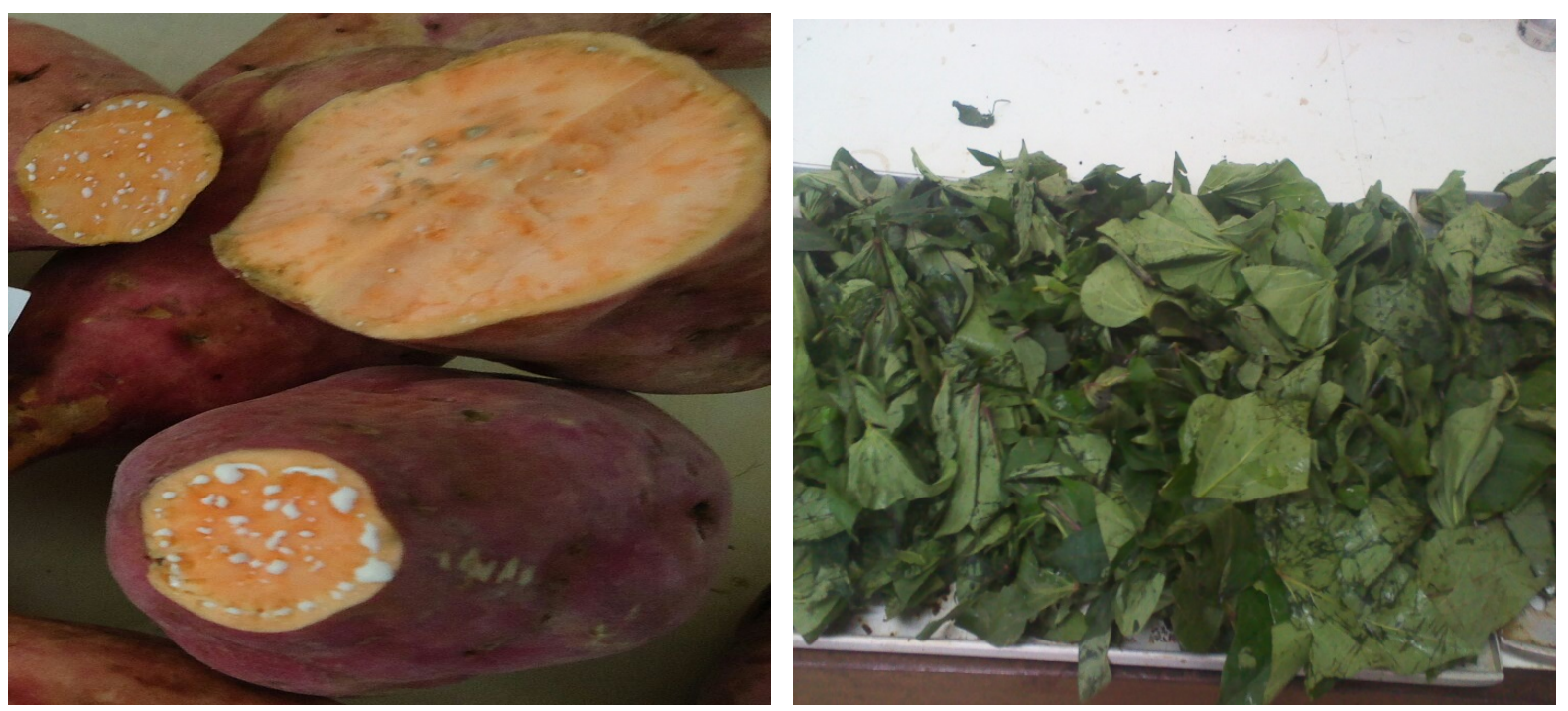

Figure 2. Morphological pictures orange fleshed sweet potato roots and leaves.

\subsection{Precooking Sweet Potato Roots}

Sweet potato roots were precooked at a temperature of $75^{\circ} \mathrm{C}$ for two hours to enhance starch hydrolysis to enable production of sweet flakes. These parameters were decided based on the idea that alpha-amylase enzymes are heat stable up to a temperature of $70^{\circ} \mathrm{C}-75^{\circ} \mathrm{C}$ as reported by Ikemiya and Deobald (1966) [19]. Cooking to boiling for 20 minutes was done by increasing the temperature. This was done to soften the root to enable easy mashing of the roots for mixing with the leaves.

\subsection{Blending the Sweet Potato Leaves and Roots}

The sweet potato mashed roots and the ground sweet potato leaves were blended as shown in Table 1. A starting quantity of ground sweet potato leaves was chosen as $10 \%$ of the total composite. The quantity was increased at 
Table 1. Combination ratios between the sweet potato roots and leaves.

\begin{tabular}{|ccccccc}
\hline Individual constituents & \multicolumn{5}{c}{ Percent blending ratios } \\
\cline { 2 - 7 } & T1 & T2 & T3 & T4 & T5 & T6 \\
\hline Ground sweet potato leaves (\%) & 0 & 10 & 20 & 30 & 40 & 50 \\
Mashed sweet potato roots (\%) & 100 & 90 & 80 & 70 & 60 & 50 \\
\hline
\end{tabular}

intervals of $10 \%$ until the composite contained the maximum acceptable amount of leaves.

\subsection{Analytical Methods}

\subsubsection{Sample Preparations}

Orange fleshed sweet potato root and leaves were obtained from KARI, Muguga center and were analyzed before and after processing. Before processing, the roots and leaves were washed and then macerated to a smooth puree in a conventional kitchen type electric blender (model NO. BL 60603G, China) and then samples drawn for analysis.

\subsubsection{Proximate Composition Analysis}

Standard methods of AOAC [20] were used for the determination of the ash, Crude Protein, dry matter and crude fibre contents.

\subsubsection{Starch Content}

Duplicate samples of $100 \mathrm{~g}$ of orange fleshed sweet potato roots were measured accurately and diced and then homogenized with $100 \mathrm{ml}$ of water in a kitchen blender (model NO. BL 60603G, China) for 5minutes. The aqueous fraction containing suspended starch was collected by screening through fine nylon. The residue was recycled twice with the same amount of water and screened through a nylon cloth after each recycling in the blender. All the aqueous fraction was collected together and balanced out in two (4) centrifuge bottles and centrifuged for 10 minutes at about $3000 \mathrm{rpm}$. The supernatant was gotten rid of and the scum on top of the starch cake removed and the surface rinsed with a little water and suspended in a little water and centrifuged again and the cleaning steps repeated. Finally the starch was purified in a Buchner funnel lined with Whatman paper No. 1 by percolating water, $95 \%$ ethanol and acetone through the starch and the starch content determined on a dry matter basis

\subsubsection{Determination of $\beta$-Carotene}

Total carotenoids from the sweet potato were extracted as described by Khachik (1992) [21]. Total beta carotene was then determined spectrophotometrically (CE 4400/UV Vis Double Beam Scanning Spectrophotometer, Cambridge, England) as described by Imungi and Potter (1983) [22].

\subsubsection{Sensory Evaluation of Flakes}

Sensory evaluation was based on 7-point hedonic scale [23]. Twenty semi-trained panelists were randomly selected in the University of Nairobi and the panel was composed of both students and staff from the Department of Food Science, Nutrition and Technology. The sensory attributes included colour, taste, texture and overall acceptability. Panelists were informed that their honest opinion was important. A sip of water were taken in between samples to cleanse the palate before tasting the next product [24] [25]. The scale used was: $1=$ dislike extremely, 2 = dislike very much, 3 = dislike moderately, 4 = neither like nor dislike, 5 = like moderately, 6 = like very much, 7 = like extremely.

\subsection{Statistical Analysis}

Samples were analyzed in duplicates and the data generated analyzed using analysis of variance (ANOVA) and comparison of means carried out using least significant difference test (LSD) calculated at 5\% using GenStat $15^{\text {th }}$ edition. 


\section{Results and Discussion}

\subsection{Proximate Composition of Sweet Potato Roots and Leaves}

Table 2 shows the average proximate composition of raw orange fleshed sweet potato roots and orange fleshed sweet potato leaves.

The dry matter (DM) content of Orange Fleshed Sweet Potato (OFSP) roots was 28.1\%. The DM of roots were significantly $(\mathrm{p}<0.05)$ higher than the dry matter content of the sweet potato leaves which was relatively low at $18.5 \%$. The DM of the sweet potato leaves reported in the current study was comparable to the value of 17.7\% reported by Antia (2006) [27]. On comparing the DM of sweet potato leaves to other vegetables, the value found in the current study is higher compared to the values of $10.0 \%-12.8 \%$ in common vegetables reported by Asaolu (2007) [26]. This shows that the sweet potato leaves contain more dry matter and hence more nutrients and should be considered for human consumption.

The dry mater content of the roots found in this study was higher than $27.16 \%$ which was reported in the US Department of Agriculture, Nutrient database of 2001 [29]. Other studies have reported dry matter content of fresh sweet potato roots to be ranging between 28.78 and $40.9 \%$ [28] which are higher than the values found in the current study.

The starch content for the roots was $86.87 \%$ on DM basis. The starch content of the roots was significantly (p $<0.05$ ) higher than the starch content of the leaves which was $50.96 \%$ on DM basis. There is therefore an adequate quantity of starch for hydrolysis to sugars to enhance the sweetness of the flakes. Omodamiro (2013) [28] reported starch content of the roots to be ranging between 71.79 and $80.95 \%$ on DM basis which was lower compared to the values found in the current study. US Department of Agriculture, Nutrient database of 2001 [29] reported starch content of $89.4 \%$ on DM basis. This was slightly higher than the values presented in the current study.

The protein content of the OFSP roots used in the current study was found to be $6.64 \%$ on DM basis. This value is close to the figure of $6.22 \%$ on DM basis which was reported by US Department of Agriculture, Nutrient data base of 2001 [29]. On the other hand this value was quite low compared to the results of Omodamiro (2013) [28] who reported very high protein content in the sweet potato roots that ranged from $13.7 \%$ to $16.9 \%$ on DM basis. The high value reported by Omodamiro (2013) [28] could be possibly due to the different varieties. The low protein in the roots as indicated in the current study necessitates means of increasing its content in food products of sweet potato origin especially to a population who need protein for body building like children.

The protein content of the sweet potato leaves was $24.16 \%$ which was significantly $(\mathrm{p}<0.05)$ higher compared to the protein content of the roots. The protein content found in the current study was comparable to the result reported by Antia (2006) [27] who reported crude protein of sweet potato leaves to be $24.85 \%$ on DM basis when he analyzed the proximate composition of the leaves. The leaves being significantly higher in protein than the roots are a suitable and a very cheap source of protein to supplement the low protein content of the sweet potato root. During harvesting, the leaves are usually wasted and left to dry on the field and hence can be made good use of in increasing the protein content of the sweet potato flakes. This will provide a way in which sweet potato leaves can be consumed especially in Kenya where most of the population does not consume the leaves directly.

The ash content of the OFSP roots was found to be $3.18 \%$ on DM basis. This was a little lower compared to the results reported in the US Department of Agriculture, Nutrient database of 2001 [29] which gave 3.5\% ash on DM basis but it was similar to the values reported by Omodamiro (2013) [28] who gave a range of $1.74 \%$ to $3.72 \%$ on DM basis. The ash content of the sweet potato leaves was found to be $11.43 \%$ on DM basis and was significantly $(\mathrm{p}<0.05)$ higher than that of the sweet potato roots. The value closely compares to ash content of

Table 2. Composition of orange fleshed sweet potato roots and leaves on dry matter basis.

\begin{tabular}{|c|c|c|c|c|c|c|}
\hline & Dry matter (\%) & Starch content (\%) & Protein content (\%) & Total sugars (\%) & Total ash (\%) & $\beta$-carotene (mg/100g) \\
\hline Roots & $28.1 \pm 0.14^{\mathrm{a}}$ & $86.87 \pm 0.07^{\mathrm{a}}$ & $6.64 \pm 0.04^{\mathrm{a}}$ & $15.21 \pm 0.01$ & $3.18 \pm 0.04^{\mathrm{a}}$ & $8.65 \pm 0.10^{\mathrm{a}}$ \\
\hline Leaves & $18.5 \pm 0.14^{\mathrm{b}}$ & $50.96 \pm 0.08^{b}$ & $24.16 \pm 0.14^{\mathrm{b}}$ & ND & $11.43 \pm 0.04^{\mathrm{b}}$ & $0.53 \pm 0.03^{b}$ \\
\hline
\end{tabular}

Values are means of duplicate determinations plus or minus standard deviation; ND = not determined. Values with similar letters in the same column are not significantly different at $5 \%$. 
dried sweet potato leaves that was reported to be $11.10 \%$ by Antia (2006) [27]. Sun (2014) [30] reported ash content ranging between 7.39 and $14.66 \%$ which is within the range found in the current study. This indicates a higher mineral content of the leaves that have been shown to include calcium, magnesium, phosphorus and sodium [30]. Also in the ash are trace elements which include iron, zinc, copper, manganese and selenium. This makes sweet potato leaves even a better supplement as it would also provide a variety of minerals and trace elements which may not be provided adequately in daily diets.

The $\beta$-carotene content in OFSP root was found to be $8.65 \mathrm{mg} / 100 \mathrm{~g}$. The OFSP roots can provide much higher $\beta$-carotene than the RDA for Vitamin A which is measured in retinol equivalents (RE) as a means of making standard comparisons among foods [31]. The $\beta$-carotene therefore represents $720 \mathrm{RE}$. The RDA of various age groups are; for infants: 0 - 6 months require $400 \mu \mathrm{g} /$ day while 6 - 12 months require $500 \mu \mathrm{g} /$ day, children: 1 - 3 years require $300 \mu \mathrm{g} /$ day while 4 - 8 years require $400 \mu \mathrm{g} / \mathrm{day}$, males: 9 - 13 years require $600 \mu \mathrm{g} / \mathrm{day}$ while those who are14 years and above require $900 \mu \mathrm{g} /$ day, females: 9 - 13 years require $600 \mu \mathrm{g} /$ day while those who are 14 and above require $700 \mu \mathrm{g} /$ day, pregnant women: 14 - 18 years require $750 \mu \mathrm{g} / \mathrm{day}$ while those who are above 18 years require $770 \mu \mathrm{g} /$ day and the lactating mothers: 14 - 18 years $1200 \mu \mathrm{g} /$ day while those above 18 years require $1300 \mu \mathrm{g} / \mathrm{day}$ [32]. Burgos (2001) [33] found out that the $\beta$-carotene content varied with the intensity of colouration of the sweet potatoes. They also found out that the $\beta$-carotene content of cream fleshed sweet potato ranged from 0.0 to $0.4 \mathrm{mg} / 100 \mathrm{~g}$ and that deep orange coloured sweet potatoes ranged from $4.29 \mathrm{mg} / 100 \mathrm{~g}$ to $18.55 \mathrm{mg} / 100 \mathrm{~g}$. This shows that the result of the current study was within this range. The results are also similar to those reported by Teow (2007) [34] which were in the range of 4.45 to $22.6 \mathrm{mg} / 100 \mathrm{~g}$.

The level of carotenoids could be used as a means of choosing the variety for processing as this plays an important role in the overall acceptability and enhances the nutritional image of the flakes [35]. Processing $\beta$-carotene rich sweet potato to produce acceptable flakes is likely to be a cost effective means of alleviating vitamin A deficiency on a mass scale. The $\beta$-carotene in the sweet potato leaves was found to be significantly $(\mathrm{p}<0.01)$ lower compared to those of the sweet potato roots. The $\beta$-carotene content of the leaves make it a better vegetable that could be made use of to provide a variety of nutrients which may not be provided by the other vegetables. The reported $\beta$-carotene found in the present study was $0.53 \mathrm{mg} / 100 \mathrm{~g}$ on DM basis in the sweet potato leaves.

\subsection{Characteristics of Sweet Potato Flakes}

Adding sweet potato leaves to the roots significantly $(\mathrm{p}<0.05)$ increased the protein content of the flakes (Figure 3). A 40\% leaf content composite has more than double the initial protein content of the sweet potato roots. This makes the flakes more nutritious in terms of protein. They also provide the energy potatoes are known for.

Increasing the sweet potato leaves reduced the beta carotene content significantly $(p<0.05)$ as indicated in Figure 4. However, the levels in flakes can provide more than the recommended daily allowance (RDA) of vitamin A as reported by Molybdenum (2001) [28].

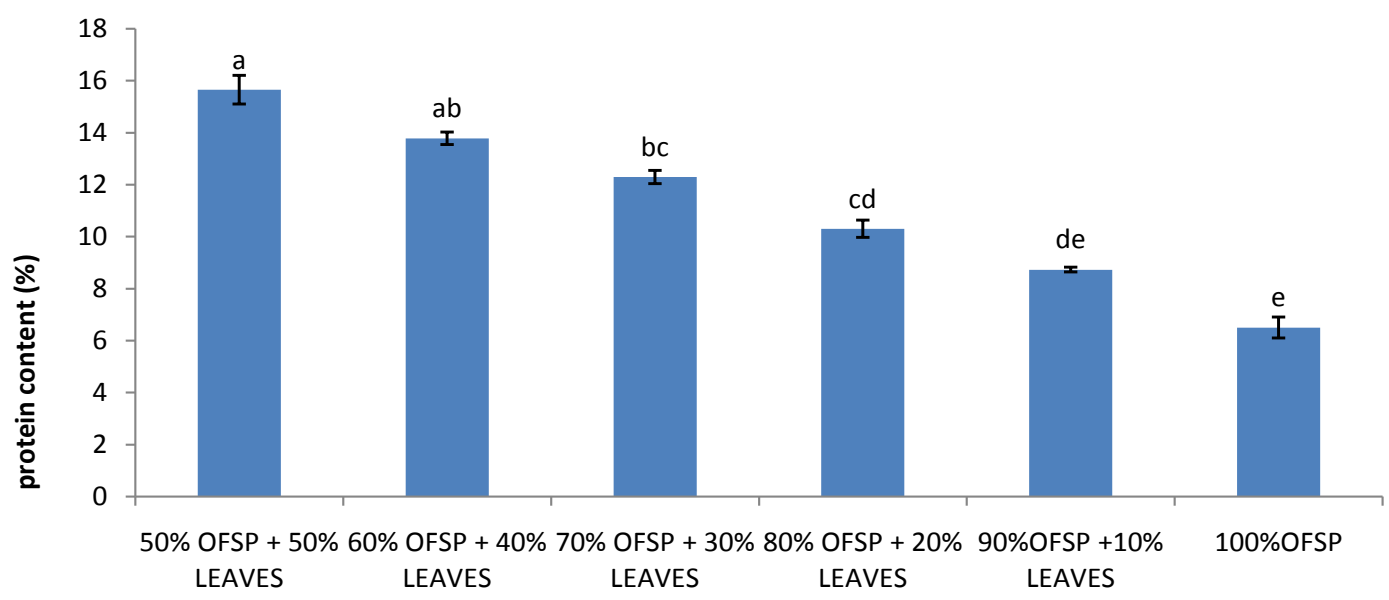

Figure 3. Average amount of protein in OFSP root-leaf flakes. The bars show the standard error of mean. The bars with different letters show that there is significant difference at $5 \%$ level of significance. 


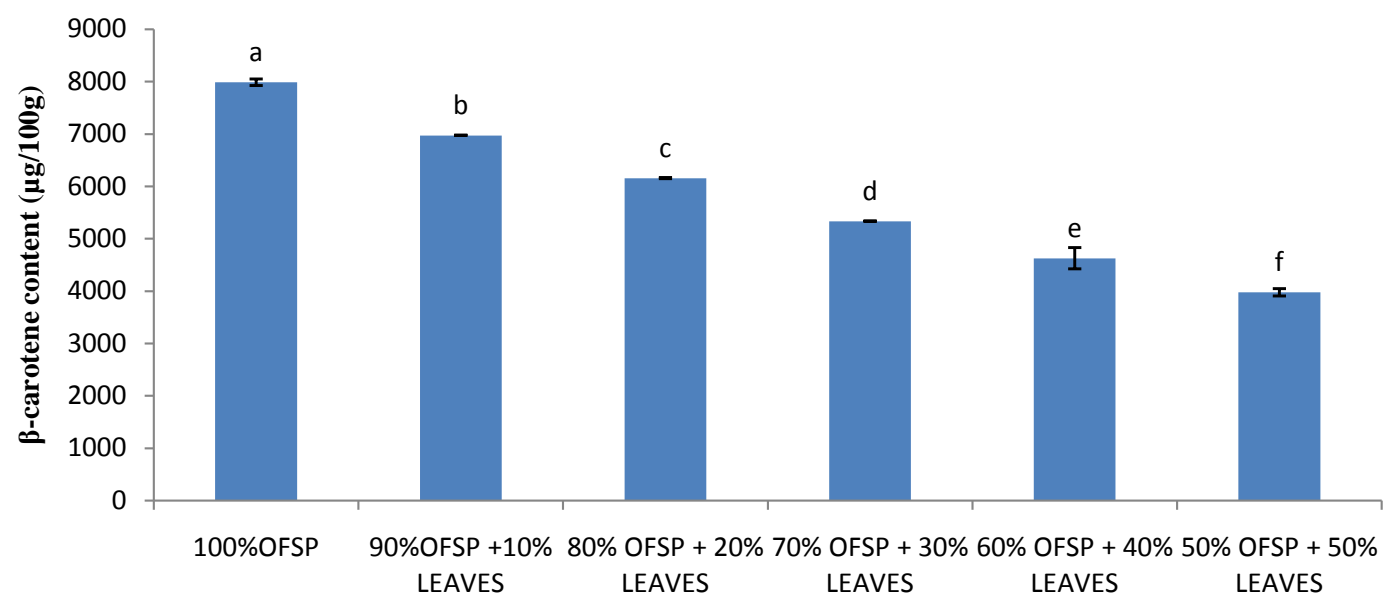

Figure 4. Average amount of beta carotene in OFSP root-leaf flakes. The bars show the standard error of mean. The bars with different letters show that there is significant difference between them at $5 \%$ level of significance.

\subsection{Sensory Analysis}

The sweet potato flakes presented to the panel varied in appearance as shown in Figure 5. The results of sweet potato flakes with enriched protein sensory evaluation were as shown in Table 3.

\subsubsection{Colour}

Addition of sweet potato leaves to the tuber significantly $(\mathrm{p}<0.05)$ affected the colour of the flakes. The flakes containing $100 \%$ roots was the most accepted with an average score of 6.62. This decreased as more sweet potato leaves were added with the flakes containing $40 \%$ leaves scoring a mean score of less than 4 showing they were not acceptable to the panelists. Addition of leaves may only be done up to $30 \%$ if the product has to be acceptable using visual color, beyond which acceptability is greatly reduced.

\subsubsection{Taste}

Addition of sweet potato leaves to the tuber significantly $(\mathrm{p}<0.05)$ affected the taste of the flakes with $100 \%$ roots getting a mean score of 6.75 . The addition of the leaves reduced the acceptability with one of the treatment containing $50 \%$ leaves being rejected since it had a mean score of less than 4 . The current results show that it is possible to add leaves up to $40 \%$ percent and the taste will still be acceptable.

\subsubsection{Texture}

Texture was the most highly scored parameter which means that it was the most accepted quality attribute with a mean score for all the treatments being 5.92. Despite this the addition of the leaves to the roots significantly ( $\mathrm{c}$ 0.05) affected the score for flakes. All the treatments for the flakes were acceptable in terms of texture with the least mean score for the treatment being 4.12, no mastication problems irrespective of the amount of leaves added.

\subsubsection{Overall Acceptability}

Scores for overall acceptability revealed that all the treatments were accepted by the panelists with the least mean score being 4.12 which is above 4 while the average mean score for all the treatments was 5.52 . It is, however, noted that the addition of the leaves to the roots significantly $(\mathrm{p}<0.05)$ lowered the overall acceptability of the flakes.

\section{Conclusions}

Addition of sweet potato leaves to the roots increases the nutritional content of the flakes mainly in terms of protein while still maintaining the high beta carotene to levels that can meet the recommended daily allowance. 


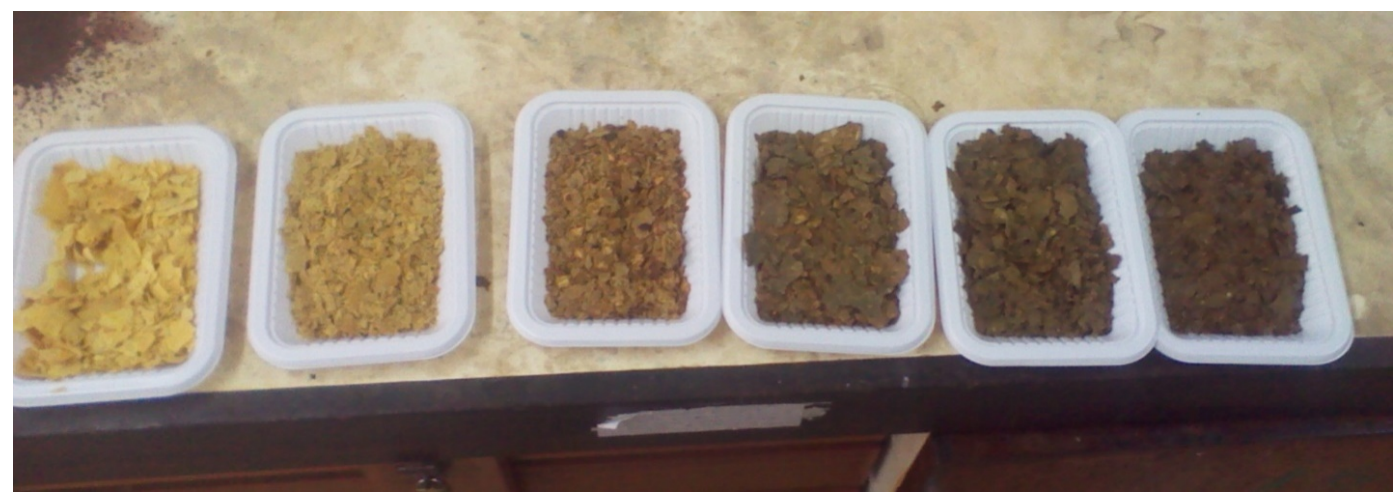

Figure 5. Sweet potato flakes. From left to right are T1, T2, T3, T4, T5 and T6 respectively.

Table 3. Mean sensory attributes scores for different flakes formulations.

\begin{tabular}{|c|c|c|c|c|c|c|}
\hline Attribute & $\mathbf{T 1}$ & $\mathbf{T} 2$ & T3 & T4 & T5 & T6 \\
\hline Colour & $6.62^{\mathrm{a}}$ & $5.88^{\mathrm{b}}$ & $5.75^{c}$ & $4.12^{\mathrm{d}}$ & $3.38^{d}$ & $2.75^{\mathrm{e}}$ \\
\hline Taste & $6.75^{\mathrm{a}}$ & $6.50^{\mathrm{b}}$ & $6.00^{\mathrm{c}}$ & $4.88^{\mathrm{d}}$ & $4.25^{\mathrm{e}}$ & $3.13^{f}$ \\
\hline Texture & $6.75^{\mathrm{a}}$ & $6.75^{\mathrm{a}}$ & $6.25^{\mathrm{b}}$ & $5.75^{\mathrm{c}}$ & $5.25^{\mathrm{d}}$ & $5.13^{\mathrm{d}}$ \\
\hline Overall acceptability & $6.63^{\mathrm{a}}$ & $6.50^{\mathrm{ab}}$ & $6.13^{\mathrm{abc}}$ & $5.00^{\text {bcd }}$ & $4.75^{\mathrm{cd}}$ & $4.12^{\mathrm{d}}$ \\
\hline
\end{tabular}

Values are mean of ten panels. Same letters along the row indicate there is no significant difference between the treatments (p $>0.05$ ).

Addition of the leaves to the root significantly ( $\mathrm{p}<0.05$ ) adversely affects the taste, colour, texture and the overall acceptability of the flakes. Despite this, incorporation of sweet potato leaves up to the level of $30 \%$ of the composite results in flakes that are nutritious and acceptable.

\section{Acknowledgements}

Department of Food Science, Nutrition and Technology, University of Nairobi is highly acknowledged for their invaluable financial and technical support.

\section{References}

[1] FAOSTAT (2013) Statistical Database (Online) of Food and Agriculture Organization of the United Nations.

[2] Burri, B.J. (2011) Evaluating Sweet Potato as an Intervention Food to Prevent Vitamin A Deficiency. Comprehensive Reviews in Food Science and Food Safety, 10, 118-130. http://dx.doi.org/10.1111/j.1541-4337.2010.00146.x

[3] International Potato Center (2009) Sweet Potato Initiative for Profit and Health Brochure. http://www.cipotato.org/research/partnerships-and-special-projects/sasha-program

[4] Haskell, M.J., Jamil, K.M., Hassan, F., Peerson, J.M., Hossain, M.I., Fuchs, G.J. and Brown, K.H. (2004) Daily Consumption of Indian Spinach (Basella alba) or Sweet Potatoes Has a Positive Effect on Total-Body Vitamin A Stores in Bangladeshi Men. American Journal of Clinical Nutrition, 80, 705-714.

[5] Van Jaarsveld, P.J., Faber, M., Tanumihardjo, S.A., Nestel, P., Lombard, C.J. and Spinnler Benadé, A.J. (2005) $\beta$ Carotene-Rich Orange-Fleshed Sweet Potato Improves the Vitamin A Status of Primary School Children Assessed with the Modified-Relative-Dose-Response Test. American Journal of Clinical Nutrition, 81, 1080-1087.

[6] Low, J.W., Arimond, M., Osman, N., Cunguara, B., Zano, F. and Tschirley, D.A. (2007) Ensuring the Supply of and Creating Demand for a Biofortified Crop with a Visible Trait: Lessons Learned from the Introduction of OrangeFleshed Sweet Potato in Drought-Prone Areas of Mozambique. Food Nutrition Bulletin, 28, 258-270.

[7] Low, J.W., Arimond, M., Osman, N., Cunguara, B., Zano, F. and Tschirley, D. (2007) A Food-Based Approach Introducing Orange-Fleshed Sweet Potatoes Increased Vitamin A Intake and Serum Retinol Concentrations in Young Children in Rural Mozambique. Journal of Nutrition, 137, 1320-1327.

[8] West Jr., K.P. (2002) Extent of Vitamin A Deficiency among Preschool Children and Women of Reproductive Age. Journal of Nutrition, 132, 2857-2866. 
[9] United Nations Childrens Fund (UNICEF) (2004) Micronutrient Initiative. Vitamin and Mineral Deficiency, a Global Progress Report [Internet]. Ottawa, Canada: UNICEF. http://www.micronutrient.org/CMFiles/PubLib/VMd-GPR-English1KWW-3242008-4681.pdf

[10] Black, R.E., Allen, R.H., Bhutta, Z.A., Caulfield, L.E., de Onis, M., Ezzati, M., Mathers, C. and Rivera, J. (2008) Maternal and Child Undernutrition: Global and Regional Exposures and Health Consequences. Lancet, 371, $243-260$. http://dx.doi.org/10.1016/S0140-6736(07)61690-0

[11] Bovell-Benjamin, A.C. (2007) Sweet Potato: A Review of Its Past, Present, and Future Role in Human Nutrition. Advanced Food Nutrition Resources, 52, 1-59. http://dx.doi.org/10.1016/S1043-4526(06)52001-7

[12] Walter, M.W. and Hoover, M.W. (1984) Effects of Pre-Processing Storage Conditions on the Composition, Microstructure and Acceptance of Sweet Potato Patties. Journal of Food Science, 49, 1258-1261. http://dx.doi.org/10.1111/j.1365-2621.1984.tb14965.x

[13] Woolfe, J.A. (1992) Sweet Potato: An Untapped Food Resource. Cambridge University Press and the International Potato Center (CIP), Cambridge.

[14] Islam, M.S., Yoshimoto, M., Terahara, N. and Yamakawa, O. (2002) Anthocyanin Compositions in Sweet Potato (Ipomoea batatas L.) Leaves. Bioscience, Biotechnology and Biochemistry, 66, 2483-2486. http://dx.doi.org/10.1271/bbb.66.2483

[15] Islam, M.S., Yoshimoto, Y. and Yamakawa, O. (2003) Distribution and Physiological Functions of Caffeoylquinic Acid Derivatives in Leaves of Sweet Potato Genotypes. Journal of Food Science, 68, 111-116. http://dx.doi.org/10.1111/j.1365-2621.2003.tb14124.X

[16] Ishiguro, K., Kumagai, T., Kai, Y., Nakazawa, Y. and Yamakawa, O. (2002) Genetic Resources and Breeding of Sweetpotato in Japan. In: Rmanatha, R. and Campilan, D., Eds., Exploring the Complementarities of in Situ and ex Situ Conservation Strategies for Asian Sweet Potato Genetic Resources, Asian Network for Sweet Potato Genetic Resources, Bogor, 57-61.

[17] Ishiguro, K., Toyama, J., Islam, M.S., Yoshimoto, M., Kumagai, T., Kai, Y. and Yamakawa, O. (2004) Suioh, a New Sweetpotato Cultivar for Utilization in Vegetable Greens. Acta Horticulturae, 637, 339-345.

[18] Dansby, M.A. and Bovell-Benjamin, A.C. (2003) Sensory Characterization of a Ready-to-Eat Sweet Potato Breakfast Cereal by Descriptive Analysis. Journal of Food Science, 68, 706-709. http://dx.doi.org/10.1111/j.1365-2621.2003.tb05736.x

[19] Ikemiya, M. and Deobald, H.J. (1966) New Characteristics of Alpha-Amylase in Sweet Potatoes. Journal of Agricultural and Food Chemistry, 14, 237-241. http://dx.doi.org/10.1021/jf60145a011

[20] AOAC (2010) Official Methods of Analysis of Association of Analytical Chemist. 17th Edition, Washington DC.

[21] Khachik, F., Beecher, G.R., Goli, M.B. and Lusby, W.R. (1992) Separation and Quantitation of Carotenoids in Foods. Methods in Enzymology, 213, 347-359. http://dx.doi.org/10.1016/0076-6879(92)13136-L

[22] Imungi, J.K. and Potter, N.N. (1983) Nutrient Content of Raw and Cooked Cowpea Leaves. Journal of Food Science, 48, 1252-1254. http://dx.doi.org/10.1111/j.1365-2621.1983.tb09204.x

[23] Iwe, M.O. (2002) Handbook of Sensory Methods and Analysis. Rojoint Communication Services Ltd, Uwani-Enugu.

[24] ASTM (1989) Standard Definitions of Terms Relating to Sensory Evaluation of Materials and Products. In: Annual Book of ASTM Standards, American Society for Testing and Materials, Philadelphia, 19-22.

[25] Jellinek, G. (1985) Sensory Evaluation of Food: Theory and Practice. Ellis Horwood, Chichester, 34.

[26] Asaolu, S.S., Adefemi, O.S., Oyakilome, I.G., Ajibulu, K.E. and Asaolu, M.F. (2007) Proximate and Mineral Composition of Nigerian Leafy Vegetables. Journal of Food Research, 1, 214-218.

[27] Antia, B.S., Akpan, E.J., Okon, P.A. and Umoren, I.U. (2006) Nutritive and Anti-Nutritive Evaluation of Sweet Potatoes (Ipomoea batatas) Leaves. Pakistan Journal of Nutrition, 5, 166-168. http://dx.doi.org/10.3923/pjn.2006.166.168

[28] Omodamiro, R.M., Afuape, S.O., Njoku, C.J., Nwankwo, I.I.M., Echendu, T.N.C. and Edward, T.C. (2013) Acceptability and Proximate Composition of Some Sweet Potato Genotypes: Implication of Breeding for Food Security and Industrial Quality. International Journal of Biotechnology and Food Science, 1, 97-101.

[29] US Department of Agriculture, Agriculture Research Service (2001) Nutrient Database for Standard Reference, Release 14. Government Printing Office, Washington DC.

[30] Sun, H.N., Mu, T.H., Xi, L.S., Zhang, M. and Chen, J.W. (2014) Sweet Potato (Ipomoea batatas L.) Leaves as Nutritional and Functional Foods. Journal of Food Chemistry, 156, 380-389. http://dx.doi.org/10.1016/j.foodchem.2014.01.079

[31] Williams, S.R. and Worthington-Roberts, B.S. (1988) Nutrition throughout the Life Cycle. Times Mirror/Mosby College Publishing, St. Louis. 
[32] Molybdenum, Nickel, Silicon, Vanadium, and Zinc (2001) Dietary Reference Intakes for Vitamin A, Vitamin K, Arsenic, Boron, Chromium, Copper, Iodine, Iron, Manganese. www.nap.edu

[33] Gabriela, B., Carpio, R., Sanchez, C., Paola, S., Edouardo, P., Espinoza, J. and Grunerberg, W. (2001) A Color Chart to Screen for High Beta-Carotene in Orange Fleshed Sweet Potato Breeding. International Potato Center, Lima.

[34] Teow, C.C., Truong, V.D., Mc Feeters, R.F., Thompson, R.L., Pecota, K.V. and Yencho, G.C. (2007) Antioxidant Activities, Phenolic and Beta-Carotene Contents of Sweet Potato Genotypes with Varying Flesh Colors. Journal of Food Chemistry, 103, 829-838. http://dx.doi.org/10.1016/j.foodchem.2006.09.033

[35] Troung, V.D. and Fermentira, G.B. (1988) Formulation, Consumer Acceptability and Nutrient Content of Nonalcoholic Beverages from Sweet Potatoes. Visayas State College, Baybay. 